\title{
Al'Ad̂̂́lah \\ KEPEMIMPINAN KYAI SALAF DI PONDOK PESANTREN AL-HASANI AL-LATIFI BONDOWOSO
}

\author{
Mustajab \\ Fakultas Tarbiyah dan Ilmu Keguruan IAIN Jember \\ mustajabiainjember@gmail.com
}

\begin{abstract}
As the oldest and typical Indonesian educational institution, pesantren has a significant role in educating the nation's children. the character of education and leadership is very influential on the students character who are the younger generation. Besides that, pesantren in the archipelago are very diverse when viewed from the aspect of the material character being taught, the teaching methods, the students quantity, the leadership model of their leaders, the characteristics of their movements, and their affiliation to Islamic movements in the archipelago. Pesantren salaf which have survived until now seen as special pesantren, because such pesantren considered as institutions that are able to maintain their existence in the midst of information which is a catalyst for change in the society. Therefore, leadership in the Pesantren salaf is very interesting to be observed. This dissertation tries to discuss the types and styles of leadership of pesantren in the modern world at two salaf pesantren located in Bondowoso Regency. Namely, Pesantren Kauman Al-Hasani Al-Lathifi. The result is leadership in the Salaf Al-Hasani Al-Latifi is leadership based on lineage and wise autocratic character. Its style is a delegative leadership style.
\end{abstract}

Keywords: Leadership, Islamic Boarding School of Salaf

\section{Pendahuluan}

Fenomena kepemimpinan kiai masih sangat menarik untuk didiskusikan. Hal ini tentu menempatkan kiai sebagai agent of change dalam setiap konstalasi perubahan sosial, yakni kiai eksis dengan Pondok Pesantren untuk menyuarakan progress kehidupan ke arah yang lebih baik, lebih-lebih pada saat ini banyak kiai yang turun gunung untuk meramaikan dinamika politik. Sebagaimana dikatakan Dhofier, kiai adalah gelar yang diberikan oleh masyarakat kepada orang ahli agama Islam yang memiliki atau menjadi pengasuh pondok pesantren dan mengajar kitab-kitab Islam klasik kepada para santrinya. Sedangkan istilah kiai memiliki kaitan yang erat dengan status yang diberikan kepadanya, yakni sebagai pengasuh sekaligus pemilik pondok pesantren. Sebagai pengasuh dan pemilik pondok pesantren, maka peran kiai dalam pondok pesantren sangat sentral.

Kiai di pesantren adalah penggerak dalam mengemban dan mengembangkan 
pesantren sesuai dengan pola yang dikehendakinya, karena di tangan seorang kiai, pesantren tetap eksis sampai saat ini. Oleh sebab itu, kiai dan pesantren merupakan dua sisi yang selalu berhubungan erat secara dinamis. Sebagai pemimpin di pesantren, kebijakan-kebijakan kiai sangat berpengaruh terhadap sistem, arah, visi, dan misi pesantren, lebih-lebih kiai yang memiliki kemampuan kepemimpinan yang amat disegani oleh para santri, alumni, simpatisan dan masyarakat luas, sehingga dapat dipastikan kiai yang demikian memiliki garis komando yang kuat dan ditaati oleh bawahannya.

Visi misi, tujuan, dan pemikiran serta faham keagamaan kiai bagi para pengurus pesantren dan para santri merupakan hal yang dikagumi dan menjadi amanah yang harus dilaksanakan, bukan karena keterpaksaan tetapi justru karena ketaatan dan persetujuan dari para pengurus maupun santrinya terhadap kiai yang memimpin dan sekaligus pemilik pesantren. ${ }^{1}$ Sosok kiai seakan-akan menjadi magnet bagi semua lapisan masyarakat, sehingga eksistensinya dapat menjelma menjadi figur karismatik di lingkungan pondok pesantren maupun di luar pesantren.

Pondok Pesantren Salafiyah Al-Utsmani Beddian adalah pesantren yang mengikuti sistem salaf dalam lembaga pendidikannya. Tipe kepemimpinan kiai dalam lembaga pendidikan ini menarik untuk diteliti, sebab sekalipun menggunakan sistem pendidikan salaf, pesantren sejauh ini dianggap mampu merespons segala perkembangan zaman yang terjadi. Ini ditandai dengan tetap stabilnya jumlah santri yang menempuh pendidikan di pesantren Salafiyah Al-Utsmani Beddian.

Pondok Pesantren Salafiyah Al-Utsmani Beddian terletak di Desa Beddian \pm 3 $\mathrm{km}$ dari Kecamatan Jambesari Darussholah dan $\pm 10 \mathrm{~km}$ dari pusat Kota Bondowoso. Podok Pesantren Salafiyah Al-Utsmani merupakan salah satu lembaga pendidikan pesantren otonom yang terlepas dari kurikulum yang ditawarkan oleh pemerintah. Pesantren ini mengikuti kurikulum dan sistem pembelajaran yang pernah diterapkan Pondok Pesantren Tempurejo Jember. Otonomi tersebut memberikan keleluasaan bagi kiai dan staf-stafnya untuk memilih tipe sistem pembelajaran yang dikehendaki dan disesuaikan dengan visi misi muassis (pendiri) Pondok Pesantren Al-Utsmani Baddian, yakni KH Ghazali. Sedangkan visi pesantren ini pada awal didirikan adalah mempertahankan kelestarian ajaran $A b\}$ l al-Sunnab $W$ a al-Jama $>^{\prime}$ ah . Sedangkan sistem yang diterapkan di pesantren ini adalah sistem salafiyah.

Peneliti sengaja mengambil obyek penelitian tentang kepemimpinan kiai Pesantren Al-Utsmani Beddian dengan sistem salafiyah, karena kiai memiliki pengaruh serta kharisma yang kuat, khususnya bagi masyarakat Kabupaten Bondowoso dalam menjaga tradisi salafiyah syafi'iyah. Selain sebagai penjaga tradisi salaf, pengasuh dalam kepemimpinanya menjauhkan diri dari dinamika politik, sehingga pengasuh Pondok Pesantren Al-Utsmani Beddian menjadi tumpuan seluruh masyarakat karena sikap netralitasnya terhadap partai politik. Dengan sikap ini pengasuh hanya memfokuskan

${ }^{1}$ Zamakhsyari Dhofir, Tradisi Pesantren: Studi Tentang Pandangan Hidup Kiai (Jakarta: LP3ES, 1985), 8. 
diri pada pemberdayakan umat melalui pendidikan di Pondok Pesantren. Karena itulah kiai Pesantren Al-Utsmani menjadi figur leader khususnya bagi para santri-santrinya dalam menjalankan roda kepemimpinan di Pondok Pesantren.

Kiai berpengaruh kuat pada bawahannya. Sebab itu, kiai sebagai pimpinan sebuah lembaga pendidikan di pesantren perlu melakukan perubahan sesuai tuntutan lingkungan masyarakat. Dalam menghadapi perubahan, pimpinan pesantren perlu merumuskan visi secara jelas dan relevan dengan perkembangan zaman. Sedangkan pengurus pesantren adalah tim yang menjalankan pengelolaan sebuah pesantren dengan berlandaskan pada visi yang jelas, sehingga mudah bagi pengurus pesantren untuk menjalankan, menterjemahkan, dan mewujudkan visi serta misi kiai dengan baik dan benar.

Hal Ini berarti bahwa apabila kiai sebagai pimpinan pesantren memiliki visi dan misi yang jelas, maka para pengurus pesantren akan lebih memahami apa yang hendak dilaksanakan dalam mengelola pesantren di masa mendatang, sehingga segala kegiatan dan program yang disusun oleh para pengurus pesantren akan berjalan sesuai dengan harapan dan cita-cita kiai sebagai pengasuh dan pemimpin pesantren.

Fenomena yang terjadi saat ini banyak pondok pesantren salaf tetap mempertahankan sistem salafiyah dalam sistem pembelajarannya yang memiliki ciri-ciri sebagai berikut: 1) Menjadikan kitab-kitab kuning klasik sebagai materi pokok dalam kurikulum pesantren; 2) Tidak mengajarkan materi umum seperti pesantren semi modern dan modern; 3) Lulusan dari pesantren ini tidak mendapat ijazah resmi dari pemerintah seperti lulusan madrasah lembaga pendidikan Islam formal; 4) Tidak mengenal batasan waktu pelaksanaan pembelajarannya karena tidak memakai sistem ijazah. Santri akan pulang kalau sudah mendapat izin dari kiai meski yang bersangkutan sudah lulus di madrasah diniyah pesantren tersebut; 5) Karena hanya mempelajari ilmuilmu kitab kuning saja, pendidikannya cenderung bersifat akhirat oriented yang dapat dilihat dari peraturan pasantren seperti larangan bersekolah ke sekolah umum; 6) Menjunjung tinggi nilai-nilai agama seperti nilai spiritual beribadah pada Allah, keikhlasan, kesabaran, ketaatan pada kiai dan ustadh, etika dan sopan santun kepada sesama manusia.

Pesantren Al-Utsmani Beddian ditetapkan sebagai objek penelitian dikarenakan memiliki tipe pesantren salaf yang memiliki visi yang luhur, yakni mempertahankan ajaran $A b\}$ l al-Sunnab $W$ a al-jama $>$ 'ah yang dikemas dalam sistem pembelajaran kitabkitab kuning sebagai acuan utama dalam referensi materi pembelajaran dan pengembangannya pada kurikulum yang bersifat umum. Hal ini terkait dengan landasan berpikir pengasuh Pondok Pesantren Al-Utsmani Beddian yang perlu untuk diketahui dalam penelitian ini, karena landasan berpikir pengasuh mempengaruhi sistem yang diterapkan dalam pendidikan di pesantren.

Pola pengkaderan kepemimpinan yang dilakukan oleh kiai PP. Al-Hasani AlLathifi dalam menyiapkan penggantinya adalah melalui pendidikan kepemimpinan secara intensif kepada putranya. Pertama, putranya mewakili kiai menghadiri acara 
undangan dalam melayani umat. Kedua, pengkaderan ke dalam yang dilakukan kiai dalam membantu tugas-tugasnya, karena tugas kiai di dalam pesantren lebih kompleks, tidak hanya mengajarkan ilmu agama yang diwakili 'usta $>d h /$ 'usta $>$ dhah tetapi melaksanakan tugas yang lain sebagai penerima amanah dari wali santri. ${ }^{2}$ Kiai di pondok pesantren masing-masing memiliki tipe kepemimpinan yang berbeda serta memiliki kesamaan dalam memimpin pondok pesantren, terutama bila dihadapkan dengan kondisi globalisasi saat ini. ${ }^{3}$ Kiai dari masing-masing pondok pesantren memiliki karakter kepemimpinan, baik visi, misi, maupun paradigma dalam mempertahankan sistem pendidikan salaf.

\section{Pembahasan}

\section{Model Kepemimpinan Pondok Pesantren Salaf Al-Hasani Al-Lathifi}

Kepemimpinan Pondok Pesantren Salaf Al-Hasani Al-Lathifi terjadi secara alamiah, dan kiai merupakan tokoh sentral yang memiliki otoritas penuh. Tugas terbagi menjadi bagian-bagian yang lebih kecil sesuai dengan wewenang masing-masing, yang pada substansinya merupakan satu kesatuan yang tidak terpisahkan.

Model pengambilan keputusan di Pesantren Kauman Al-Hasani Al-Lathifi, menempatkan kiai sebagai pemegang otoritas tertinggi dalam pengambilan keputusan. Tetapi pada persoalan teknis dan lapangan, kiai menyerahkan wewenang kepada pengurus untuk melakukan dan menentukan keputusan sendiri sesuai wewenangnya.

Kepemimpinan Pesantren Pondok Al-Hasani Al-Lathifi menerapkan tipe kepemimpinan otokratik, akan tetapi kepemimpinan otokratik di sini tidak sebagaimana yang diterapkan pada kepemimpinan perusahaan, sebab tipe kepemimpinan ini biasanya diterapkan oleh seorang presiden direktur dalam suatu perusahaan besar. Biasanya pada tipe ini pemimpin merumuskan masalahnya serta menyodorkan cara pemecahannya sekaligus. Kemudian perumusan masalah dan pemecahannya itu dijual kepada bawahannya, sehingga para bawahan sering membenci atas kebijakan-kebijakan yang dikeluarkan oleh pimpinannya, di mana ia menentukan kebijakan secara keras, kasar, dan tidak memberikan ruang gerak bagi para karyawannya untuk mengelak, memberikan alasan, berargumen dan mempertahankan keberadaannya.

Dalam tipe kepemimpinan otokratik, pemimpin bersikap sebagai penguasa dan yang dipimpin sebagai yang dikuasai. Termasuk tipe ini, sebagaimana terurai pada bab II dapat dijumpai pemimpin-pemimpin yang: a) Mengatakan segala sesuatu yang harus dikerjakan oleh mereka yang dipimpin. Inilah gaya kepemimpinan diktator. Yang dilakukan oleh pemimpin yang mengambil gaya ini hanyalah memberi perintah, aturan dan larangan. b) Menjual gagasan dan cara kerja kepada kelompok orang yang dipimpinnya. ${ }^{4}$

Berbeda dengan kepemimpinan otokratik di pesantren, yang lebih mengarah pada

${ }^{2}$ Wawancara dengan Ustad Suhaeri, pada tanggal 15 Agustus 2013.

${ }^{3}$ Muhaimin, Wacana Pengembangan Pendidikan Islam (Yogyakarta: Pustaka Pelajar, 2004), 24.

${ }^{4}$ A.M. Mangunhardjana, SJ., Kepemimpinan (Yogyakarta: Penerbit Kanisius, 2004), 21-22. 
"otokratik-kebapakan". Bedanya adalah bahwa respons bawahan (para ustadh maupun santri) tetap merasa senang, sadar, semangat untuk mengikuti dan melaksanakan kebijakan yang dikeluarkan oleh seorang kiai. Inilah yang menarik untuk diteliti, mengapa mereka mengikuti dan dengan kesadaran diri melaksanakan apa yang disampaikan, dan diperintahkan kiainya, tanpa harus menolak atau bahkan menentangnya.

Peneliti menemukan alasan para santri selalu mengikuti kebijakan yang dikeluarkan kiainya adalah mengamalkan ilmu yang telah diperoleh oleh para santri dari pengkajian kitab Ta'lim al-Muta'alim-nya Syaik Zarnuji yang selalu diajarkan sebagai kitab pedoman menuntut ilmu di pesantren.

Sebagai orang yang memiliki otoritas yang mutlak dalam hal pengambilan keputusan di pondok pesantren, pengasuh dengan model kepemimpinannya masih menjalankan tipe kepemimpinan delegatif. Hal ini dilakukan oleh pengasuh sematamata untuk melakukan kaderisasi kepemimpinan. Gaya kepemimpinan delegatif yang dijalankan oleh pengasuh yaitu dengan memberi kewenangan yang penuh kepada pengurus pesantren tentang kebijakan-kebijakan teknis. Ini artinya pengasuh mendelegasikan tanggung jawab secara utuh kepada pengurus pesantren agar mereka belajar bertanggung jawab atas apa yang direncanakan/atau diputuskan dengan apa yang telah dilaksanakan.

Meskipun Pondok Pesantren Kauman al-Hasani Al-Lathifi memiliki krakter salaf tidak semuanya salaf, namun pengertian salaf di sini terbatas pada komponen kurikulum pesantren saja. Begitu pula dengan Pondok Pesantren Al-Utsmani Beddiyan Jambisari meskipun terbilang salaf, pola kepemimpinannya sudah menggunakan prosedur modern.

Ciri khas pondok pesantren adalah menekankan pengajaran mengenai ta'dzim (menghormati, memuliakan, mengagungkan) kepada guru, mengagumi ilmu, dan kekhusyukan perilaku. Sehingga para santri merasa rendah hati (tawadhu'), mengagungkannya dan selalu mengharapkan segala petunjuk berupa apa pun dari kiainya. Selain itu, juga terdapat ajaran "Sami'an wa ta'atan" yaitu taat pada ulama, mau mendengarkan sesuatu yang menjadi nasihat kiai untuk kemudian taat dan mengimplementasikan dalam kehidupan sehari-hari.

Dalam diri para santri sudah melekat dan tertanam rasa percayanya dan pengakuan keilmuan dan kebenaran ajaran yang disampaikan oleh kiainya. Ajaran "tabarruk" (berharap berkah) juga menjadi bagian dari rangkaian ajaran yang ditekankan di pesantren.

Kecenderungan "kharismatik keagamaan" ditunjukkan dengan kewibawaan kepemimpinan kiai. Kiai diangkat menjadi seorang pemimpin selain karena akhlaknya dan ilmu agamanya, juga karena keturunan para sesepuh atau parapendahulunya. Gaya pelaksanaan tugas kepemimpinannya terkadang otokratik dan suatu saat menerapkan demokratik. Gaya kepemimpinan ini sangat efektif bila diterapkan pada pesantren salaf yang masih mempertahankan ciri khasnya sebagai pesantren yang mengkaji kitab 
kuning, namun juga ingin menyesuikan atau mengikuti perkembangan zaman yang serba canggih.

Tipe kepemimpinan otokratik akan efektif jika diterapkan dalam keadaan yang mendukung (tepat), contohnya fatwa-fatwa yang dikeluarkan oleh sesepuh, khususnya berkaitan dengan permasalahan hukum Islam (figh), tasawuf (akhlak), dan akidah (Ahlus Sunnah Wal Jamaah). Selain itu, terdapat kebijakan-kebijakan tertentu yang diyakini harus dilaksanakan oleh semua santri dan pengurus pondok. Misalnya peraturan/tata tertib pondok, saran sesepuh, peringatan sesepuh, dan lain-lain. Tipe kepemimpinan demokratik lebih efektif dilakukan ketika berkaitan dengan pengembangan kelimuan yang tidak bertentangan dengan syariat Islam dan peraturan pesantren. Misalnya bebas memilih untuk mengikuti t\}ariqah apa saja, diperbolehkan menuntut ilmu yang tidak diajarkan di pesantren, seperti sekolah formal (SMP, SMA, kuliah), kursus, olah raga, dan lain sebagainya.

Kepemimpinan di Pondok Pesantren Al-Hasani Al-Lathifi telah berimplikasi pada kegiatan yang ada di pondok pesantren. Kegiatan yang dilakukan di Pondok Pesantren Kauman Al-Hasani Al-Lathifi terdiri dari dua jalur pembelajaran, yakni pembelajaran ma'badiah (kepesantrenan) dan pembelajaran jalur madrasah.

Selain berdampak pada iklim kegiatan di pondok pesantren, pola kepemimpinan ini telah berdampak pada pola pengkaderan yang ada di pondok pesantren. Pola pengkaderan kepemimpinan yang dilakukan kiai di Pondok Pesantren Kauman mencakup dua model. Pertama, pengkaderan yang dilakukan oleh pengasuh/kiai dalam menyiapkan penggantinya kelak di kemudian hari. Kedua, pengkaderan ke dalam, pengkaderan ini bisa diamati dengan dibentuknya beberapa kepala bidang pondok pesantren, yaitu sebagai berikut: kepala bidang keamanan, kepala bidang ubudiyah, kepala bidang kebersihan dan kesehatan, serta kepala bidang tarbiyah.

Di samping pola kepemimpinan ini berdampak pada kaderisasi yang ada di pondok pesantren, dengan pola kemimpinan ini juga terbentuk nilai utama yang ada di pondok pesantren. Nilai tersebut di antaranya rangkaian kerja berorientasi ibadah dengan menekankan pada praktek fiqh-tasawwuf, penekanan akhlak santri, dan penanaman nilai keikhlasan dan ketulusan.

Pola kepemimpinan otokratis di PP. Al-Hasan Al-Lathifi juga berdampak pada sistem jaringan, sehingga terbentuk dua model jaringan yaitu jaringan internal dan eksternal. Jaringan internal di sini adalah jaringan pesantren yang memiliki hubungan kekeluargaan dengan pesantren, seperti faktor genealogi nasab dengan memanfaatkan ikatan keluarga yang diwadahi dengan nama organisasi Ikbal (Ikatan Keluarga Bani Abdul Lathif). Jaringan internal kedua adalah alumni dan wali santri yang turut menopang keberlanjutan pesantren, dari alumni walaupun tidak ada sumbangan materi khusus dari alumni namun, eksistensi dan kharisma juga sangat dipengaruhi oleh seberapa besar alumni sebuah pondok pesantren tersebar. Jaringan eksternal yaitu mencakup koneksi yang dilakukan pondok pesantren dengan instansi pemerintah

Selain model kepemimpinan otokratis dengan gaya delegatif berdampak pada 
lembaga-lembaga pendidikan, model ini pula telah berdampak pada lembaga dakwah. Pengasuh pondok pesantren dengan gaya otokratisnya telah menjadi media sosial bagi masyarakat Bondowoso dan sekitarnya membantu masyarakat dalam menuntaskan persoalan sosial dan pemberdayaan masyarakat sebagai wujud kontribusinya menuntaskan persoalan sosial. Media yang digunakan sebagai wujud kepedulian ini telah terbentuk menggunakan buletin santri yang bernama "Medika" (Media Kauman) untuk alumni sekaligus sebagai sarana untuk tetap menyambung silaturrahim santri (pesantren) atau alumni.

Peran kiai dalam dakwah sebagai mobilisator dalam menggerakan perjalanan dakwah khususnya di pondok pesantren, karena kiai merupakan penafsir tunggal terhadap sumber Islam. Dalam pengkaderan yang dilakukan di Pesantren Kauman melakukan bimbingan dakwah dengan adanya pelatihan orasi. Dalam frame ini, bisa dilihat bahwa tipologi kepemimpinan Pondok Pesantren Salaf Al-Hasani Al-Lathifi adalah dengan menggunakan model otokratis di mana keputusan-keputusan dan kebijakan-kebijakan mengenai arah perjalanan pondok pesantren mutlak berasal dari pengasuh selaku tokoh sentral di dalam pondok pesantren.

Secara teoritik, kepemimpinan otokratis adalah model kepemimpinan yang tidak menyenangkan, mensejahterakan, dan melindungi bawahannya. Hal ini dikarenakan karakteristik pimpinan menganggap bahwa organisasi/lembaga adalah miliknya sendiri. Pimpinan bersikap otoriter terhadap para anggota organisasinya dengan asumsi mereka adalah para bawahan dan merupakan sebagai alat, bukan sebagai manusia.

Ciri-ciri pemimpin otokratis adalah sebagai berikut: a) menganggap organisasi sebagai pemilik pribadi; b) mengidentikkan tujuan pribadi dengan tujuan organisasi; c) menganggap bawahan semata mata sebagai alat; d) tidak mau menerima kritik, saran, dan pendapat; e) terlalu tergantung pada kekuasaan formalnya; f) menggunakan pendekatan yang mengandung unsur paksaan. Begitu juga dalam menggerakkan anggota organisasi, pemimpin denga tipe kepemimpinan ini memakai unsur-unsur paksaan dan ancaman-ancaman pidana. Bawahan hanya menurut dan menjalankan perintah-perintahnya tidak membantah karena pemimpinan model otokratis adalah pemimpin anti kritik, saran maupun pendapat. Kepemimpinan model ini juga sebuah kepemimpinan yang dikendalikan oleh seseorang yang mempunyai harga diri tinggi, orang lain dianggap bodoh bahkan dianggap tidak ada, tidak berpengalaman dan layak untuk dibimbing.

Secara teoritik kepemimpinan otokratis dianggap tidak baik, namun berbeda jika yang terjadi di lingkungan pondok pesantren, pesantren bisa dikatakan krajaan kecil, di mana raja berkuasa penuh atas singgasananya, begitu pula yang terajadi di Pondok Pesantren Salaf Al-Hasani Al-Lathifi, pengasuh tidak pernah semena-mena dalam mengambil keputusasnnya, karena otoritasnya disandarkan pada nilai-nilai agama. Sehingga, tidak sama secara teoritis dengan model kepemimpinan otokratis pada umumnya.

Dari tipe kepemimpinan Pondok Pesantren Salaf Al-Hasani Al-Lathifi yang 
otokratis tersebut, pengasuh selaku tokoh sentral masih memiliki kekuasan yang mutlak, pengurus harian diberi kesempatan untuk mengusulkan ide atau pemikiran terkait dengan proses pendidikan di pesantren. Biasanya setiap seminggu sekali pada malam Jum'at ada rapat koordinasi yang dilakukan oleh pengurus. Hasil dari rapat pengurus terkait kebijakan strategis pesantren diajukan kepada kiai, misalnya penentuan liburan pondok, dan penentuan iuran akhir tahun. Namun pada sisi lain, yang berjalan di Pondok Pesantren Kauman sudah tersistem dengan rapi.

Dalam pandangan teori kepemimpinan yang berorientasi pada hasil, kiai tidak terlalu mementingkan bagaimana cara yang dilakukan oleh para bawahan. Yang penting adalah sesuatu yang ditargetkan tercapai. Pola dasar kepemimpinan ini melahirkan beberapa tipe kepemimpinan yang sangat sesuai dengan kepemimpinan yang diperaktikan oleh pengasuh Pondok Pesantren Al-Hasani Al-Lathifi adalah tipe otokrasi yang bijak. Dalam konteks ini, pemimpin biasanya lebih tertib, ahli dalam mengorganisir, dan ketat dalam menerapkan peraturan-peraturan. ${ }^{5}$

Dalam kenyataan ini, tipe kepemimpinan pengasuh Pondok Pesantren Salaf AlHasani Al-Lathifi, adalah dengan tipe kepemimpinan delegatif yang memiliki ciri-ciri dasar: (a) Memberikan pengarahan bila diperlukan saja; (b) Memberikan dukungan dianggap tidak perlu lagi; (c) Penyerahan tanggung jawab kepada bawahan untuk mengatasi dan menyelesaikan tugas; (d) Tidak perlu memberi motivasi karena tingkat kematangan bawahan sangat tinggi. Tanggungjawab diberikan secara mutlak kepada bawahan, khususnya kepada pengurus pesantren untuk mengambil inisiatif secara pribadi yang diwenangkan kepada pengurus untuk mengambil langkah strategis dalam mengambil keputusan dalam persoalan teknis.

Kendati kiai merupakan sumber mutlak dari kekuasaan dan kewenangan (power and autority) dalam kehidupan dan lingkungan pesantren, segala perencanaan dan kebijakan yang akan diterapkan harus senantiasa melalui pertimbangan yang cukup matang. Sebab, dalam tiap perintah atau kebijakan yang diberikan kepada bawahannya akan membawa implikasi terhadap eksistensi pesantren itu sendiri.

Pimpinan Pondok Pesantren Salaf Al-Hasani Al-Lathifi sangat menyadari hal tersebut, bahwa segala apa yang akan dilakukan harus benar-benar dipertimbangkan dan tidak menjadikan kekuasaan sebagai sarana dan kekuatan untuk bertindak dan melakukan apa saja sesuai kehendak hatinya. Prinsip pemimpin Pondok Pesantren Salaf Al-Hasani Al-Lathifi ini sangat relevan dengan apa yang telah digambarkan AlQur'an tentang orang-orang yang mempunyai kekuasaan dan kekuatan dalam sebuah kepemimpinan yang berbunyi:

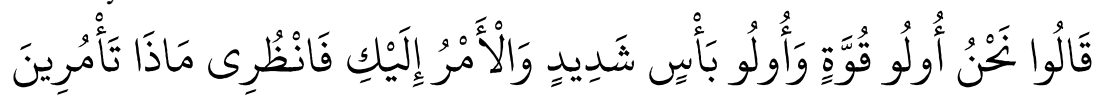

Mereka menjawab: "Kita adalah orang-orang yang memiliki kekuatan dan (juga) memiliki keberanian yang sangat (dalam peperangan), dan Keputusan berada ditanganmu: Maka

${ }^{5}$ Kartini Kartono, Pemimpin dan Kepemimpinan, 28. 
pertimbangkanlah apa yang akan kamu perintahkan".

Berangkat dari prinsip tersebut, keterlibatan pengasuh pondok pesantren cukup berhasil mengantarkan pesantren menjadi lembaga pendidikan Islam yang resposif terhadap perkembangan zaman dan akomodatif terhadap kebutuhan masyarakat di era globalisasi saat ini meskipun sistem pendidikan sendiri masih salaf murni.

\section{Implikasi Kepemimpinan Kyai di Pondok Pesantren Salaf Al-Hasani Al-Lathifi Bondowoso}

\section{Implikasi Kepemimpinan Kaderisasi Kepemimpinan Pondok Pesantren}

Praktik kepemimpinan otokratik sejatinya merupakan tipologi kepemimpinan yang sejak dulu melekat dan bahkan selalu ada dalam tiap-tiap pesantren manapun. Kebanyakan kiai Pulau Jawa beranggapan bahwa suatu pesantren dapat seperti kerajaan kecil, dengan kiai merupakan sumber mutlak dari kekuasaan dan kewenangan (power and autority) dalam kehidupan dan lingkungan pesantren. Hal ini berangkat dari latar belakang historis lahirnya lembaga pendidikan pesantren yang hampir keseluruhan merupakan hasil usaha pribadi atau individual (individual enterprise), karena dari pancaran pendirinyalah dinamika pesantren itu akan terlihat, sehingga tidak jarang kekuasaan otoriter masih cukup melekat di pondok pesantren, tidak terkecuali di Pondok Pesantren Al-Hasani Al-Lathifi.

Secara umum diketahui bahwa dalam pondok pesantren ada seorang pendiri atau keluarga dari pendiri pondok pesantren yang biasa kita kenal kiai. Dalam masyarakat Jawa dan Madura seorang kiai umumnya lebih dihargai oleh masyarakat dari pada seorang pemimpin pemerintahan. Kata-kata kiai mempunyai pengertian yang sangat luas dan sangat dalam karena seorang harus mempunyai sifat dan ciri-ciri yang sangat istimewa, misalnya harus mempunyai kharisma yang tinggi, bersih dari segala sifat yang tercela, misalnya curang, mabuk, judi dan lain-lain.

Sebagai pemimpin yang memiliki kekuasaan mutlak, pengasuh Pondok Pesantren Kauman Al-Hasani Al-Lathifi melakukan kaderisasi, baik kepada keluarga sendiri maupun kepada para santri. Pola pengkaderan kepemimpinan yang dilakukan kiai di Pondok Pesantren Kauman mencakup dua model. Pertama, pengkaderan yang dilakukan oleh pengasuh/kiai dalam menyiapkan penggantinya kelak di kemudian hari, yakni dengan melakukan pendidikan kepemimpinan secara intensif kepada putranya untuk melanjutkan estafet kepemimpinan sebagai pengasuh pesantren.

Kedua, pengkaderan ke dalam yang dilakukan kiai dalam membantu tugastugasnya, karena tugas kiai di dalam pesantren jauh lebih kompleks, bukan hanya mengajarkan ilmu agama yang kemudian diwakili oleh ustadh atau ustadhah, tetapi melaksakan tugas yang lain sebagai penerima amanah dari wali santri. Pengkaderan internal ini bisa diamati dengan dibentuknya beberapa kepala bidang pondok

\footnotetext{
${ }^{6}$ Departemen Agama RI, Al-Aliyy Al-Qur an (Jawa Barat: IKAPI Diponegoro, 1995), 302.
} 
pesantren, yaitu sebagai berikut: kepala bidang keamanan, yang bertugas untuk menjalankan tata tertib pesantren yang berkaitan dengan penegakan dan stabilitas keamanan santri, seperti santri yang melanggar tata tertib pesantren, perkelahian antar santri, santri yang telat mengikuti kegiatan pondok pesantren; kepala bidang ubudiyah, memiliki tugas untuk menjalankan aktifitas kepesantrenan yang berkaitan dengan ibadah kepesantrenan, seperti tugas jadwal ibadah salat jamaah, kegiatan pengajian santri, pembacaan sholawat, puji-pujian, atau menunjukan petugas terkait dengan ibadah; kepala bidang kebersihan dan kesehatan, yang memiliki tugas menjaga kebersihan halaman pesantren, mengontrol santri yang bertugas untuk piket membersihkan halaman pesantren, sekaligus diberi tugas untuk mengontrol kesehatan serta merawat santri yang sakit, seperti mengobati santri yang sakit, atau mengantarkan kepuskesmas maupun rumah sakit; kepala bidang tarbiyah, yang memiliki tugas untuk menjalankan tugas yang berkaitan dengan pendidikan pesantren, seperti mengatur jadwal mengajar ustadh/ustadhah, menetapkan guru mata pelajaran, menentukan jadwal tamri $>n$ masal, jadwal imtib\} an (ulangan semester), mengevaluasi nilai, mengolah nilai santri hingga menetapkan santri yang layak naik kelas atau lulus.

Kegiatan pengkaderan telah dipelajari melalui berbagai metode yang berbedabeda, tergantung pada konsepsi kepemimpinan dan pemilihan metodologi, serta penelitinya. Sehingga, studi kepemimpinan hanya memperlakukan atau dihadapkan pada suatu aspek yang sempit, seperti pengaruh bawahan atau sifat-sifat pribadi ataupun perilaku yang satu dengan yang lain dijadikan sasaran studi tanpa mengaitkan yang satu sama lain yang sebenarnya merupakan satu rangkaian persoalan di bidang kepemimpinan. ${ }^{7}$ Fred E. Fiedler dan Martin M. Chamers, dalam kata pengantar bukunyayang berjudul "Leadership and Effective Management" dikemukakan, bahwa persoalan utama kepemimpinan secara kasar dapat dibagi ke dalam tiga pertanyaan pokok, yaitu: (a) Bagaimana seseorang dapat menjadi seorang pemimpin (How one became a leader); (b) Bagaimana para pemimpin itu berperilaku (How leader behave); (c) Apa yang membuat pemimpin ituberhasil (What makes the leader effective).

Beberapa studi kepemimpinan yang telah dilakukan oleh para pakar berdasarkan pendekatan perilaku dalam menetapkan perilaku kepemimpinan yang efektif, beberapa di antaranya dapat dikaji melalui teori-teori yang berhubungan dengan perilaku, sesuai dengan kontek di atas pengasuh membantu calon pemimpin melalui pengkaderan secara internal baik kepada putranya sendiri maupun kepada para santrinya dengan membentuk keorganisasian pondok pesantren dengan konsep pembagian kewenangan, sehingga terbetuklah bidang-bidang yang menjalankan kewenangan pengasuh Pondok Pesantren Kauman Al-Hasani Al-Lathifi. Secara teoritik, langkah kaderisasi pengasuh pondok pesantren ini sesuai dengan teori kepemimpinan lingkungan.

Dalam teori kepemimpinan lingkungan, munculnya para pemimpin itu merupakan hasil pembentukan dari waktu, tempat, situasi dan kondisi. Suatu tantangan

7 Wahjosumidjo, Kepemimpinan Kepala Sekolab: Tinjanan Teoritik danPermasalahannya (Jakarta PT. Raja Grafindo Persada, 2002). 
yang hebat atau kejadian yang luar biasa dan penting akan menampilkan seseorang untuk menjadi pemimpin. R.M. Strogdill mengutip dari Person yang menyatakan adanya dua hipotesa: 1) Any particular situation plays a large part in determining leadership qualities andthe leader for that situation; 2) The qualities in an individual wich a praticuler may determine as leadership qualities are them selves the product of succession of prior leadership situation which have developed and molded him.

Sejarah juga menunjukkan bahwa tidak selalu lingkungan itu dapat menampilkan pemimpin yang diperlukan. Kasus kaderisasi yang terjadi di pondok pesantren Kauman Al-Hasani Al-Lathifi adalah semata-mata untuk membentuk karakter pemimpin yang bertanggungjawab atas tugas-tugas yang telah diamanahkan pada dirinya. Waktu, situasi dan kondisilah yang akan membentuk kepemimpinan yang ada di pondok pesantren Kauman Al-Hasani Al-Lathifi.

Sangat jelas bahwa implikasi kepemimpinan otokratis ini membentuk pola kaderisasi pondok pesantren Kauman Al-Hasani Al-Lathifi baik pada keluarga maupun pada santri-santrinya dengan mendelagasikan pada kewenangan tanggung jawab pada jabatan-jabatan struktural yang dibentuk oleh pengasuh pondok pesantren sendiri.

\section{Implikasi Kepemimpinan pada Kurikulum Pesantren}

Kurikulum yang sering kita kenal adalah seluruh usaha sekolah (lembaga pendidikan) untuk merangsang anak belajar, baik dalam lingkungan kelas, di halaman sekolah maupun di luar sekolah. Sedangkan istilah kurikulum masuk dalam dunia pondok pesantren sejak satu abad yang lalu. Oleh karena itu, dapat dikatakan bahwa sebelumnya dalam dunia pondok pesantren tidak mengenal istilah kurikulum. Hal ini disebabkan sampai saat ini belum terdapat rumusan secara eksplisit tentang tujuan pendidikan pondok pesantren.

Istilah kurikulum tidak dikenal dalam kamus sebagian pondok pesantren, terutama dalam masa sebelum perang, walau materinya ada di dalam praktek pengajaran, bimbingan rohani, dan latihan kecakapan dalam kehidupan sehari-hari di pesantren, yang merupakan kesatuan dalam proses pendidikan di pesantren. Sebagaimana yang dijelaskan di atas tentang kurikulum yang secara eksplisit tidak disebutkan dalam pondok pesantren, akan tetapi kalau ditinjau lagi pengertian kurikulum modern, maka dapat ditarik kesimpulan bahwa seperti halnya pengertian kurikulum dikaitkan dengan sekolah (lembaga pendidikan), begitu juga kurikulum bila dikaitkan dengan aktivitas pondok pesantren yang mana hal tersebut meliputi seluruh aktivitas atau kegiatan pondok pesantren, baik pada waktu jam pelajaran maupun di luar jam pelajaran. Secara sederhana, dapat dikatakan bahwa kurikulum pondok pesantren merupakan lembaga pendidikan pesantren yang mengandung aktivitas ekstra kurikuler apabila hal tersebut dipandang sebagai kegiatan di luar jam pelajaran.

Pendidikan di Pesantren Kauman tetap berpegang pada system salaf yang murni menampilkan ilmu-ilmu agama tanpa memasukan unsur pelajaran umum. Yakni, dengan tetap menyelenggarakan pendidikan madrasah yang kurikulumnya dirancang 
sendiri tanpa mengikuti atau mengadopsi kurikulum dari pemerintah. Demikian pula dengan metode pengajaran yang dilakukan di Pesantren Kauman Al-Hasani Al-Lathifi dalam prakteknya tidak lagi hanya menggunakan metode bandongan dan sorogan.

Pondok Pesantren Kauman tetap melestarikan pola lama dalam pembelajaran, namun di sisi lain juga telah banyak mengadopsi pola dan metode baru yang bertujuan untuk meningkatkan kualitas santri, seperti metode musyawarah atau bahtsul masail, hafalan, demonstrasi/praktek ibadah, dan riyadab/latihan.

Di samping itu, dalam evaluasi pendidikan santri, ada beberapa metode yang digunakan yaitu: mushafahah, tamrin massal, imtihan (ujian) semesteran, hafalan, setoran baca kitab kuning, muhadlarah, dan tes pengajian Al Qur'an.

\section{Implikasi Kepemimpinan pada Pembelajaran Pesantren}

Tipe kepemimpinan otokratik Pondok Pesantren Salaf Al-Hasani Al-Lathifi memberikan implikasi pada pembelajaran yang ada di Pondok Pesantren Pondok Pesantren Salaf Al-Hasani Al-Lathifi. Materi pembelajaran yang diberikan masih sepenuhnya pembelajaran agama yang terdapat dalam kitab kuning, atau kitab terjemahannya dengan tulisan yang masih menggunakan tulisan bahasa Madura (arab pegon). Kegiatan yang dilaksanakan di Pondok Pesantren Kauman Al-Hasani AlLathifi terdiri dari dua jalur pembelajaran, yakni pembelajaran ma'hadiyah (kepesantrenan) dan pembelajaran jalur madrasah. Sebagai pesantren salaf murni, ide desain pembelajaran ini berdasarkan ijithad pengasuh secara pribadi, baik pengalamanpengalaman semasa pengasuh masih menuntut ilmu maupun inovasi-inovasi yang lain dari pengasuh.

Kegiatan ma'ba> diyah (kepesantrenan) disampaikan pada sore hari dengan metode wetonan dan sorogan dengan pola $b$ \}alaqah dalam proses pembelajarannya. Santri kelas satu mengaji dengan menggunakan metode wetonan dengan menggunakan kitab Safinat Al-Najah, Sullam al-Taufiq, Arba'u al-Rasa il (Tarik al-Salab). Santri kelas dua mulai mengaji dengan memaknai kitab kuning dengan metode bandongan, yaitu kitab Mukhtashor Jiddan. Santri kelas tiga dan empat mengaji kitab fiqh dengan metode bandongan yakni menggunakan kitab Fath\} al-Qarib yang diselesaikan selama dua tahun. Dan untuk santri Madrasah Diniyah Tingkat Wustho, metode pembelajarannya menggunakan metode sorogan yang semuanya dilakukan oleh ustadh/ustadhah di madrasah, musholla, emperan kamar.

Kegiatan jalur kedua yaitu madrasah dilakukan setiap hari, kecuali hari Jumat atau malam Jumat yang merupakan hari libur santri. Pembelajarannya dilakukan di ruang kelas dengan beberapa metode: ceramah, mushafahah, hafalan, dan praktek. Dalam pendidikan madrasah ini dilakukan sistem evaluasi yang dilakukan setiap bulannya berupa tamrin massal, atau ujian yang dilakukan setiap enam bulan sekali, yaitu imtihan, dengan disertai setoran baca kitab kuning, setoran hafalan nadzh ham (syair) seperti kitab 'A qidat ul-'Awam, Tuh\}fat al-At\}fal'Imriti, Alfiah Ibn Malik, sesuai dengan jenjang mereka masing-masing. Hasil dari evaluasi tersebut akan dilaporkan berupa raport santri yang 
akan diberikan kepada wali santri pada akhir tahun satu hari menjelang liburan santri.

Di samping itu, dilaksanakan pula pendidikan ketrampilan untuk santri, seperti kursus menjahit, tah\} sin al-khat (kaligrafi), pertukangan yang hanya sosialisasi kesehatan, pelatihan kepemimpinan, sosialisasi HIV/AIDS, pelatihan mengenai gizi, dan lain sebagainya.

\section{Implikasi Kepemimpinan pada Nilai Pendidikan Pesantren}

Nilai utama yang ditekankan di Pesantren Kauman Al-Hasani Al-Lathifi adalah sikap untuk memandang sebuah kehidupan sebagai rangkaian keseluruhan kerja ibadah. Penanaman nilai ini sudah diperkenalkan semenjak awal santri memasuki dunia pesantren. ibadah dalam konsepsi pesantren bukan hanya ibadah mahd \}ah seperti salat, puasa, dan membaca Al Qur'an. Selain itu, pendidikan pesantren yang menekankan pada praktek figh-tasawwuf menjadi penekanan utama di pesantren ini.

Sistem nilai kedua yang berkembang di Pesantren Kauman adalah penekanan akhlak atau etika santri. Hal ini terlihat dari beberapa peraturan pesantren yang mewajibkan seluruh santri untuk menggunakan Bahasa Madura halus antar sesama santri, tidak boleh masuk kamar orang lain, masuk keluar kamar harus mengucapkan salam, berjabat tangan dengan mencium tangan ustadh, dan lain sebagainya. Sistem nilai ketiga yang tampak di pesantren ini adalah penanaman nilai keikhlasan dan ketulusan dan bekerja untuk kepentingan dan tujuan yang sama.

\section{Implikasi kepemimpinan Jaringan pada Pondok Pesantren}

Jaringan yang terbentuk di Pesantren Kauman Al-Hasani Al-Lathifi menggunakan dua model yaitu jaringan internal dan eksternal. Jaringan internal di sini adalah jaringan pesantren yang memiliki hubungan kekeluargaan dengan pesantren, seperti faktor genealogi dengan memanfaatkan ikatan keluarga yang diwadahi dengan nama organisasi IKBAL (Ikatan Keluarga Bani Abdul Lathif).

Jaringan internal kedua adalah alumni dan wali santri yang turut menopang keberlanjutan pesantren, dari alumni walaupun tidak ada sumbangan materi khusus dari alumni, namun eksistensi dan kharisma juga sangat dipengaruhi oleh seberapa besar alumni sebuah pondok pesantren tersebar. Jaringan eksternal mencakup koneksi yang dilakukan pondok pesantren dengan instansi pemerintah. Sejak diprogramkannya Wajar Dikdas 9 Tahun di Pesantren Kauman, intensitas komunikasi dengan Kementerian Agama semakin bertambah, apalagi banyak program-program pemerintah baik di tingkat kabupaten maupun provinsi yang melibatkan pondok pesantren termasuk di Pesantren Kauman yang juga dilibatkan di dalamnya, seperti pelatihan, sosialisasi, seminar, dan lain sebagainya.

\section{Implikasi Kepemimpinan Pondok Pesantren pada Lembaga Dakwah}

a. Pendekatan Dakwah

Kepemimpinan pondok pesantren terwujud pada kegiatan pengasuh dalam 
membantu masyarakat untuk menuntaskan persoalan sosial. Dalam hal ini, pengasuh menjadi tumpuan untuk konsulatsi persoalan-persaoalan, baik keluarga maupun komunitas masyarakat yang lebih besar pada pesoalan kemasyarakatan. Peran kiai dalam dakwah sebagai mobilisator dalam menggerakan perjalanan dakwah Islam khususnya di pondok pesantren, karena kiai merupakan "penafsir tunggal” terhadap sumber Islam.

Dalam pengkaderan yang dilakukan oleh pengasuh Pesantren Kauman adalah dengan cara melaksanakan bimbingan dakwah, yaitu diadakan pelatihan orasi yang dilaksanakan setiap hari Jumat pagi mulai jam 07.00-09.00 WIB. Di samping itu, setiap Rabu pagi dan Kamis pagi selepas salat Subuh, juga ada kegiatan muhadlarah, serta ada lomba orasi setiap selesai imtiban (semesteran) yang diikuti santri putra dan putri. Dengan demikian, telah dilakukan upaya untuk melatih ketrampilan santri dalam berorasi untuk menyiapkan para dai.

b. Media Dakwah

Penggunaan media dakwah yang tepat akan menghasilkan dakwah yang efektif. Dengan berkembangnya media-media dan alat-alat modern, tentunya memanfaatkan hasil kemajuan tersebut merupakan suatu hal yang baik. Di Pondok Pesantren Kauman penggunaan media dakwah sudah mulai dilakukan, yaitu terbutnya buletin santri yang bernama MEDIKA (Media Kauman) untuk alumni sekaligus sebagai sarana untuk tetap menyambung silaturrahim santri (pesantren) dan alumni. Hal itu merupakan upaya dalam menyiarkan nilai-nilai keagamaan, khususnya untuk alumni dan masyarakat sekitar. Di samping itu, alat-alat elektrinik canggih juga sudah digunakan, seperti penggunaan LCD sebagai media dakwah audio visual.

\section{c. Model Dakwah di Pondok Pesantren}

Kiai di Pondok Pesantren Kauman Al-Hasani Al-Lathifi sering diundang untuk mengisi ceramah, seperti pada acara pengajian, walimat al-ursh, walimat ul-khitan, walimat al-milad, maulid Nabi Muhammad, Isra' Mi'raj, dan sebagainya. Pada acara tersebut, pengasuh Pesantren Kamuman menyampaikan pesan-pesan agama untuk mengajak jama'ah yang hadir pada kebaikan dan menjalankan nilai-nilai agama. Selain itu, dakwah juga dilakukan dengan cara dakwah bi al- b\}al, yaitu pengiriman santri ke beberapa daerah selama 10 hari dalam bulan Ramadhan. Hal ini merupakan tujuan untuk memberikan contoh dan upaya membentuk kultur masyarakat. Tujuan lain dari penugasan santri adalah sebagai persyaratan untuk memperoleh ijazah pada tingkat madrasah ibtida'iyah

\section{Kesimpulan}

Tipe kepemimpinan di Pondok Pesantren Salaf Al-Hasani Al-Lathifi menggunakan tipe kepemimpinan demokratik. Namun demikian, demokratik yang dipraktikkan di sini adalah demokratik yang bijak, karena berlandaskan nilai-nilai religiusitas. Sedangkan gaya kepemimpinan di Pondok Pesantren Al-Hasani Al-Lathifi 
menggunakan gaya delegatif. Kepemimpinan di Pondok Pesantren Al-Utsmani adalah tipe kepemimpinan demokratis. Sedangkan gaya kepemimpinannya adalah gaya instruktif-koordinatif. Tipe dari dua institusi ini telah berimplikasi pada aspek kaderisasi dan kelembagaan. Implikasi tipe kepemimpinan pondok pesantren Al-Hasani AlLathifi dan Al-Utsmani berdampak pada pengembangan Kaderisasi, Kurikulum, Pembelajaran, Sistem Nilai, Jaringan, lembaga Dakwah Pesantren

\section{Daftar Pustaka}

Zamakhsyari Dhofir, Tradisi Pesantren: Studi Tentang Pandangan Hidup Kiai (Jakarta: LP3ES, 1985)

Muhaimin, Wacana Pengembangan Pendidikan Islam (Yogyakarta: Pustaka Pelajar, 2004), A.M. Mangunhardjana, SJ., Kepemimpinan (Yogyakarta: Penerbit Kanisius, 2004)

Departemen Agama RI, Al-Aliyy Al-Qur an (Jawa Barat: IKAPI Diponegoro, 1995)

Wahjosumidjo, Kepemimpinan Kepala Sekolah: Tinjauan Teoritik dan Permasalahannya (Jakarta PT. Raja Grafindo Persada, 2002). 